\title{
The influence of the Brazil and Malvinas Currents on the Southwestern Atlantic Shelf circulation
}

\author{
R. P. Matano ${ }^{1}$, E. D. Palma ${ }^{2,3}$, and A. R. Piola ${ }^{4,5}$ \\ ${ }^{1}$ College of Oceanic and Atmospheric Sciences, Oregon State University, Corvallis, Oregon, USA \\ ${ }^{2}$ Departamento de Física, Universidad Nacional del Sur, Bahia Blanca, Argentina \\ ${ }^{3}$ Instituto Argentino de Oceanografía, CONICET, Bahía Blanca, Argentina \\ ${ }^{4}$ Departamento de Oceanografía, Servicio de Hidrografía Naval, Buenos Aires, Argentina \\ ${ }^{5}$ Departamento de Ciencias de la Atmósfera y los Océanos, Facultad de Ciencias Exactas y Naturales, \\ Universidad de Buenos Aires, Argentina
}

Received: 7 April 2010 - Published in Ocean Sci. Discuss.: 20 April 2010

Revised: 10 September 2010 - Accepted: 19 October 2010 - Published: 30 November 2010

\begin{abstract}
The oceanic circulation over the southwestern Atlantic shelf is influenced by large tidal amplitudes, substantial freshwater discharges, high wind speeds and - most importantly - by its proximity to two of the largest western boundary currents of the world ocean: the Brazil and Malvinas currents. This review article aims to discriminate the dynamical processes controlling the interaction between this extensive shelf region and the deep-ocean. The discussion is focused on two broad regions: the South Brazil Bight to the north, and Patagonia to the south. The exchanges between the Brazil Current and the South Brazil Bight are characterized by the intermittent development of eddies and meanders of the Brazil Current at the shelfbreak. However, it is argued that this is not the only - nor the most important - influence of the Brazil Current on the shelf. Numerical simulations show that the thermohaline structure of the South Brazil Bight can be entirely ascribed to steady state, bottom boundary layer interactions between the shelf and the Brazil Current. The Malvinas Current does not show the development of eddies and meanders, but its influence on the Patagonian shelf is not less important. Models and observations indicate that the Malvinas Current not only controls the shelfbreak dynamics and cross-shelf exchanges but also influences the circulation in the shelf's interior.
\end{abstract}

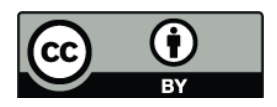

Correspondence to: R. P. Matano (rmatano@coas.oregonstate.edu)

\section{Introduction}

The southwestern Atlantic shelf extends from Cape Frio, Brazil $\left(\sim 23^{\circ} \mathrm{S}\right)$ to Burdwood's Bank $\left(\sim 55^{\circ} \mathrm{S}\right)$ (Fig. 1). Relatively narrow at its northern end, $(\sim 70 \mathrm{~km}$ near Cape Frio) it widens progressively to the south, reaching a maximum width of approximately $860 \mathrm{~km}$ near Rio Coig $\left(\sim 51^{\circ} \mathrm{S}\right)$. The coastline geometry is dominated by the jagged indentations of several gulfs in the south, the wide chasm of the La Plata estuary in the center, and the crescent shape of the South Brazil Bight in the north. The shelf circulation consists of a northward flow of cold waters in the south and a southward flow of warm waters in the north (Piola et al., 2000; Palma et al., 2008) (Fig. 1). The deep circulation is characterized by the opposing flows, and confluence, of the Brazil and Malvinas currents (Gordon, 1989). The Malvinas Current (MC) is a swift, barotropic, and narrow branch of the Antarctic Circumpolar Current that flows north along the continental slope of Argentina up to approximately $38^{\circ} \mathrm{S}$ (Matano et al., 1993). Its volume transport ranges between 40 and $70 \mathrm{~Sv}$ (Peterson, 1992; Spadone and Provost, 2009). The Brazil Current (BC) is a highly baroclinic western boundary current that concentrates the bulk of its volume transport, between 25 and $40 \mathrm{~Sv}$, in the top $500 \mathrm{~m}$ of the water column (Piola and Matano, 2001). The collision of these two currents, known as the Brazil/Malvinas Confluence, occurs near the mouth of the La Plata River where it creates a region of intense mesoscale variability.

The Sub-Tropical Shelf Front, which is located near $33^{\circ} \mathrm{S}$, divides the southwestern Atlantic shelf in two distinct regions: a northern region with warm and salty waters of

Published by Copernicus Publications on behalf of the European Geosciences Union. 


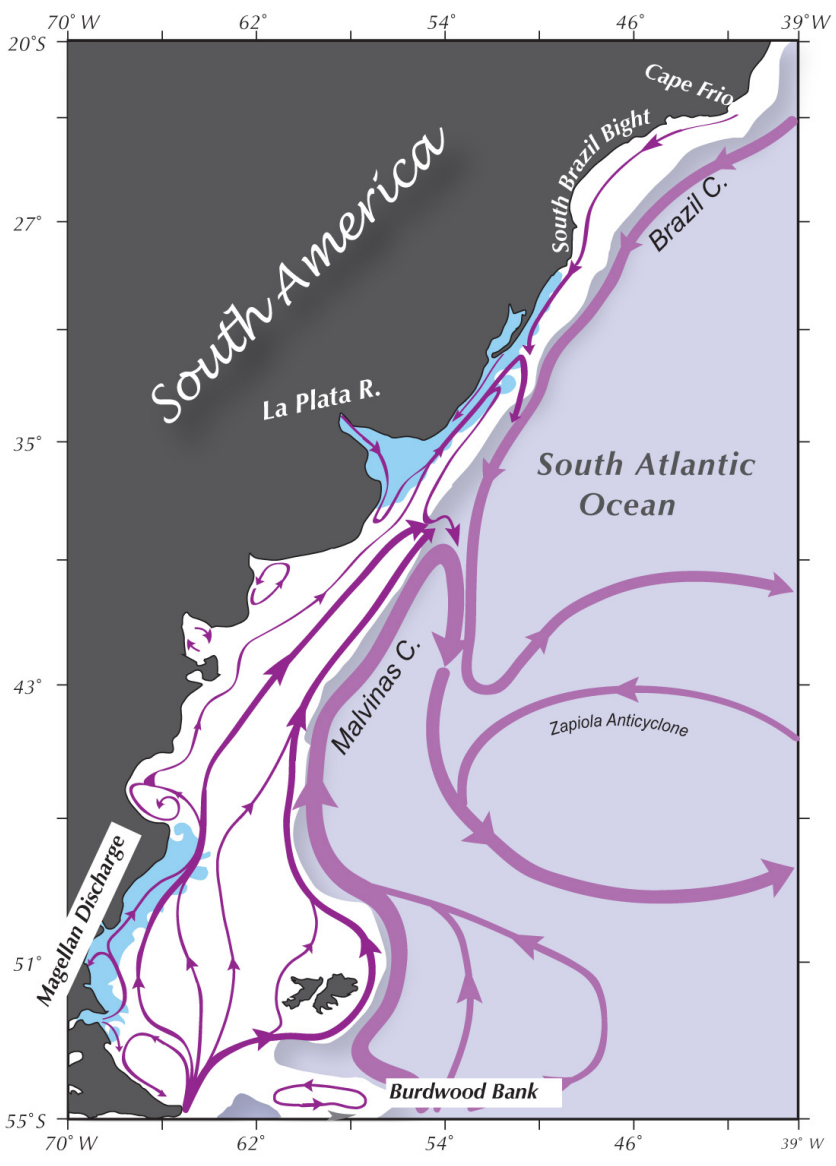

Fig. 1. Schematic representation of the depth-averaged circulation in the southwestern Atlantic region. The shelf (depths smaller than $200 \mathrm{~m}$ ) is marked by white background.

tropical and subtropical origin, and a southern region with cold and relatively fresh waters of sub Antarctic origin (Piola et al., 2000). There have been exiguous attempts to understand the influence of the $\mathrm{BC}$ and $\mathrm{MC}$ on the southwestern Atlantic shelf. Campos et al. (1995, 2000) documented penetrations of meanders of the $\mathrm{BC}$ onto the South Brazil Bight, a phenomenon dynamically similar to that observed in the eastern coast of North America (e.g., Loder et al.,1998). Palma and Matano (2009) argued that bottom boundary layer processes largely control cross-shelf exchanges in this region. There are fewer studies on the exchanges between the MC and the Patagonian shelf. Saraceno et al. (2004) noted that, unlike the $\mathrm{BC}$, the inshore boundary of the MC is remarkably stable. Malvinas waters, nevertheless, still percolate over the Patagonian shelf and influence the regional ecosystems (Piola et al., 2010). The most obvious evidence of this nutrient pumping is the high level of biological activity that is found in the Patagonia region, which is considered a Class I marine ecosystem with a productivity rate

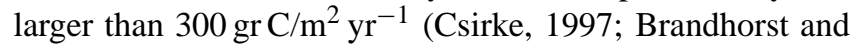
Castelo, 1971; Lutz and Carreto, 1991; Sabatini et al., 2004).
In fact, compared with Patagonia the Brazilian shelf is remarkably poor. The fish catch off southern Brazilian waters, for example, is an order of magnitude smaller than that over the Patagonia region (FAO, 2009; Haimovici et al., 2006). The interactions between the Patagonian shelf and the Southern Ocean are particularly relevant to our understanding of the global carbon budget since it is known that it absorbs large amounts of $\mathrm{CO}_{2}$ from the atmosphere (Bianchi et al., 2005, 2009). The largest absorptions are associated with high chlorophyll regions, which are presumably maintained by vigorous vertical circulations near tidal fronts and along the shelfbreak. Most of the $\mathrm{CO}_{2}$ is absorbed in austral spring and summer, but is not locally released back to the atmosphere during the winter (Bianchi et al., 2009). Assuming steady state, the net annual mean absorption of $\mathrm{CO}_{2}$ must be balanced by net export, either to the sediments or offshore. Thus, export of shelf waters near the Subtropical Shelf Front and the Brazil/Malvinas Confluence may also be a significant regional carbon sink.

Relatively little is known about the circulation over the southwestern Atlantic shelf, and much less about its exchanges with the deep ocean. In this article we review these subjects using the latest modeling and observational results. Our discussion is focused on the influence of the neighboring western boundary currents, the Brazil and Malvinas currents, on the shelf circulation. This article is organized as follows. After this introduction, in Sect. 2, we make a brief description of the numerical simulations used in the following sections. Sections 3, 4, and 5 describe the circulation and cross-shelf exchanges in the South Brazil Bight, the Patagonian Shelf, and the region of influence of the La Plata River. Section 6 summarizes and discusses the previous results.

\section{Methods}

This review is mostly focused on numerical results with comparison to observations where available. The numerical simulations are described in detail in Palma et al. (2008) and Palma and Matano (2009). Our discussion focuses on three specific experiments: EXP1 is the most realistic case and corresponds with EXP1 of Palma et al. (2008). This experiment was initialized with observations and forced with tides, QuikSCAT winds, freshwater discharges and nested to a large-scale, eddy-permitting Ocean General Circulation Model. EXP2 does not include tides or winds and corresponds with EXP2 of Palma et al. (2008). EXP3 is a barotropic experiment that was forced with tides and winds but excludes the influence of the western boundary currents on the shelf. It corresponds with EXP5 in Palma et al. (2008).

Observational data comprises hydrographic sections, surface drifters (in the deep ocean), and satellite derived SST and chlorophyll- $a$. Quality controlled historical hydrographic data were used in this analysis. The hydrographic data over the continental shelf were obtained from 
the Centro Argentino de Datos Oceanográficos (CEADO, http://www.hidro.gov.ar/ceado/ceado.asp) and Instituto Nacional de Investigación y Desarrollo Pesquero, Argentina (INIDEP, 2010), while data from the offshore region were retrieved from both, CEADO and the US National Oceanographic Data Center World Ocean Database (Boyer et al., 2009, http://www.nodc.noaa.gov/OC5/WOD09/pr wod09.html). WOCE-Surface Velocity Program type satellite tracked surface drifters drogued at $15 \mathrm{~m}$ depth were used. SvP drifters are designed to follow the water to within $\pm 013 \mathrm{~m} \mathrm{~s}^{-1}$ in $10 \mathrm{~m} \mathrm{~s}^{-1}$ winds (Niiler et al., 1995). The original position data have been quality controlled and optimally interpolated to uniform six-hour interval trajectories (Hansen and Poulain, 1996). The data are available at NOAA Atlantic Oceanographic and Meteorological Laboratory (AOML, http://www.aoml.noaa.gov/phod/index.php). The satellite chlorophyll- $a$ data are Level 3, monthly mean Standard Mapped Images of $9 \mathrm{~km}$ resolution derived from the Sea viewing Wide Field-of-view Sensor (SeaWiFS) for the period 1998-2009, provided by NASA/Goddard Space Flight Center (see O'Reilly et al., 2000).

\section{The influence of the Brazil Current on the South Brazil Bight}

The South Brazil Bight (SBB) is located between Cape Frio $\left(23^{\circ} \mathrm{S}\right)$ and Cape Santa Marta $\left(28^{\circ} 40^{\prime} \mathrm{S}\right)$ (Fig. 1). Its circulation is driven by low-amplitude tides, northeasterly winds, and the poleward flow of the $\mathrm{BC}$ along the shelf's edge. Although the region has no significant freshwater inputs, the southern portion of the bight shows intrusions of low-salinity waters from the La Plata River (Piola et al., 2000). The influence of local (e.g., winds, tides, etc) and remote forcing (e.g., the $\mathrm{BC}$ ) on the shelf circulation has marked regional variations. The inner shelf is predominantly driven by local winds while the middle and outer shelves are more influenced by the BC (Palma and Matano, 2009). The influence of the remote forcing is most obviously manifested in the SST gradients near the shelfbreak (Campos et al., 1995; Campos et al., 2000; Castelao et al., 2004), but is not confined to the surface or to the shelfbreak. In fact, the strongest influence of the BC is observed at depth, where onshore intrusions of relatively cold and fresh South Atlantic Central Waters (SACW) extend up to the coast. These intrusions are partially related to the meandering and eddy shedding of the $\mathrm{BC}$, but mostly to bottom boundary layer processes (Palma et al., 2008; Palma and Matano, 2009).

The contribution of the SACW carried by the BC to the thermohaline structure of the SBB is modulated by seasonal changes of the local wind forcing. During the summer, the SSTs over the shelf are generally higher than $23^{\circ} \mathrm{C}$, except in the northwest where a tongue of colder waters associated with the onset of upwelling favorable winds generates a strong SST front near the coast (Fig. 2a). Winter SSTs,
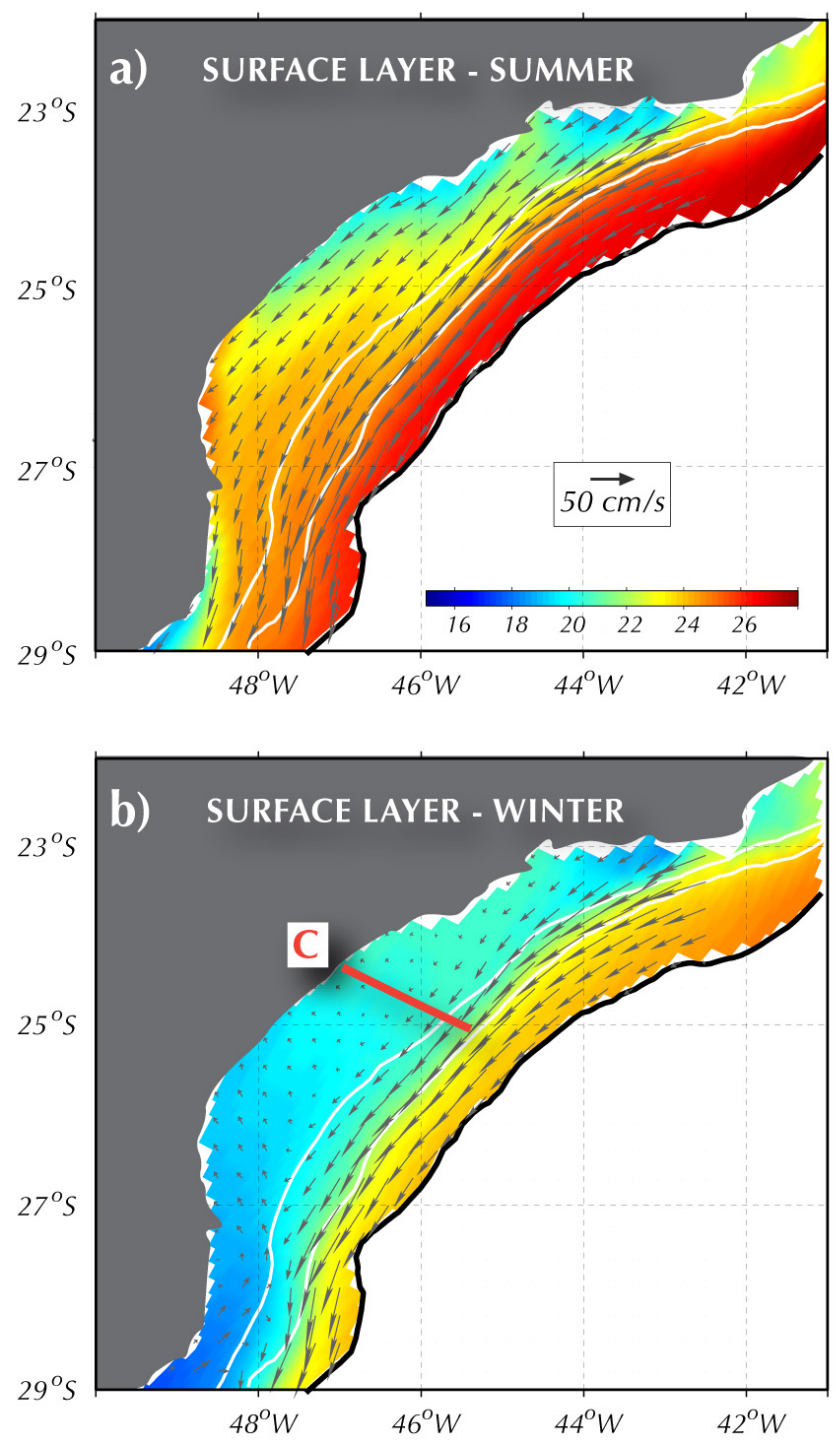

Fig. 2. Average sea surface temperatures (SSTs) and surface velocities during summer (a) and winter (b) in the numerical simulation of Palma and Matano (2009). The white line marks the position of the $100 \mathrm{~m}$ and $200 \mathrm{~m}$ isobaths. Line $\mathrm{C}$ marks the location of the cross-section shown in Fig. 3.

which are not influenced by coastal upwelling, are more homogeneous with values between $20^{\circ} \mathrm{C}$ and $23^{\circ} \mathrm{C}$ (Fig. 2b). The exception is the cold patch of low SSTs just south of Cape Frio, which is driven by onshore intrusions of the BC. SST gradients are larger near the shelfbreak due to the presence of the $\mathrm{BC}$, and in the southern portion of the bight due to the northward advection of sub Antarctic shelf waters. The seasonal changes of the SST structure are associated with changes in the ocean circulation, particularly in the middle and inner shelf. Currents are stronger in summer, when they flow in a predominantly southwestward pattern and weaken appreciably (or even reverse) in early winter (Fig. 2b). The 

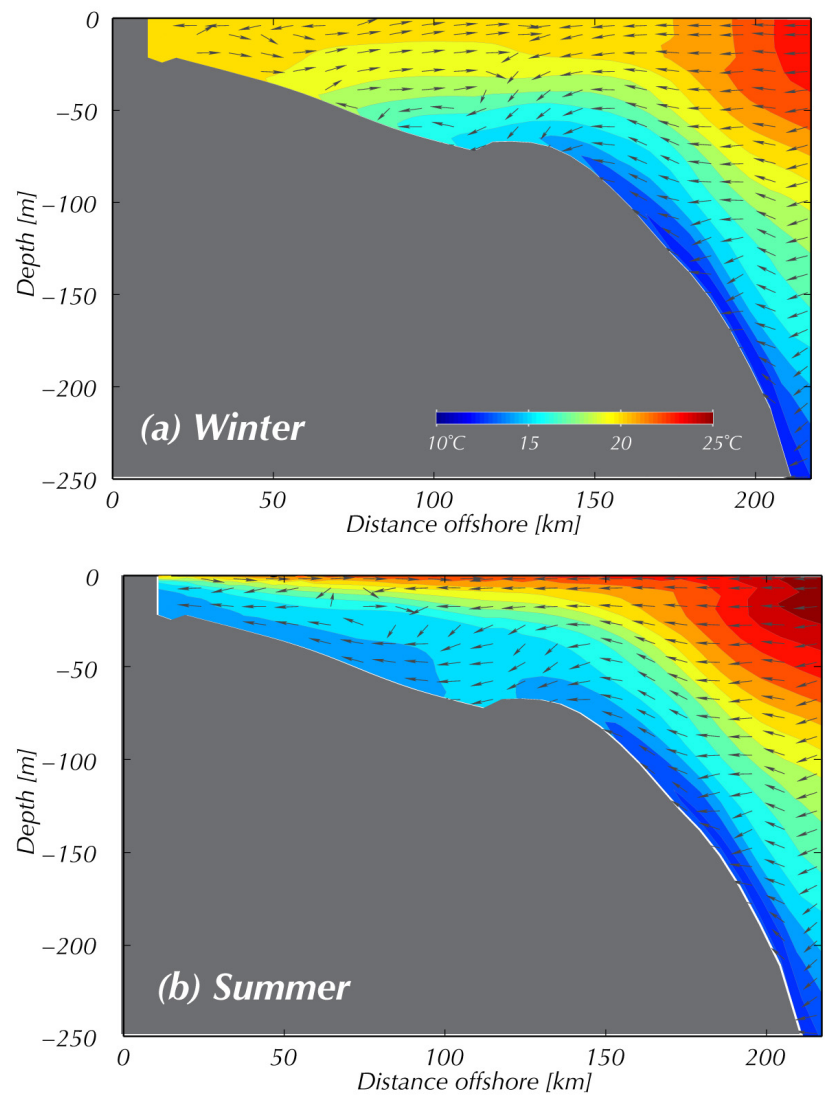

Fig. 3. Temperature and cross-shelf circulation at cross-section $C$ from EXP1. (a) Winter, (b) Summer.

influence of the BC on the SBB is most obvious in cross-shelf sections, which show subsurface tongues of cold and saltier waters from the $\mathrm{BC}$ extending from the slope to the middle shelf during the winter months (Fig. 3a). During the summer, upwelling favorable winds move these waters farther inshore where they outcrop into the surface layer (Fig. 3b).

As noted above, the water mass structure of the SBB is modulated by intrusions of the $\mathrm{BC}$ onto the middle and outer shelf, and by wind-driven upwelling in the inner shelf. The relative importance of these mechanisms has been quantified in process-oriented experiments by comparing the previous results with an experiment without tidal and windforcing (EXP2). Thus, in this experiment the only source of momentum for the shelf circulation is the presence of the BC flowing along the continental slope. The surface circulation of EXP2 is characterized by a strong southwestward flow along the outer shelf that decreases rapidly towards the coast (Fig. 4a). The summer SST field over the shelf in this experiment is nearly uniform, showing the influence of wind forcing on the observed SST structure. The contribution of the local winds to the shelf circulation is also clearly appreciated in the velocity field, which shows an almost stagnant inner shelf in EXP2 (Fig. 4a). The onshore intrusions of the BC
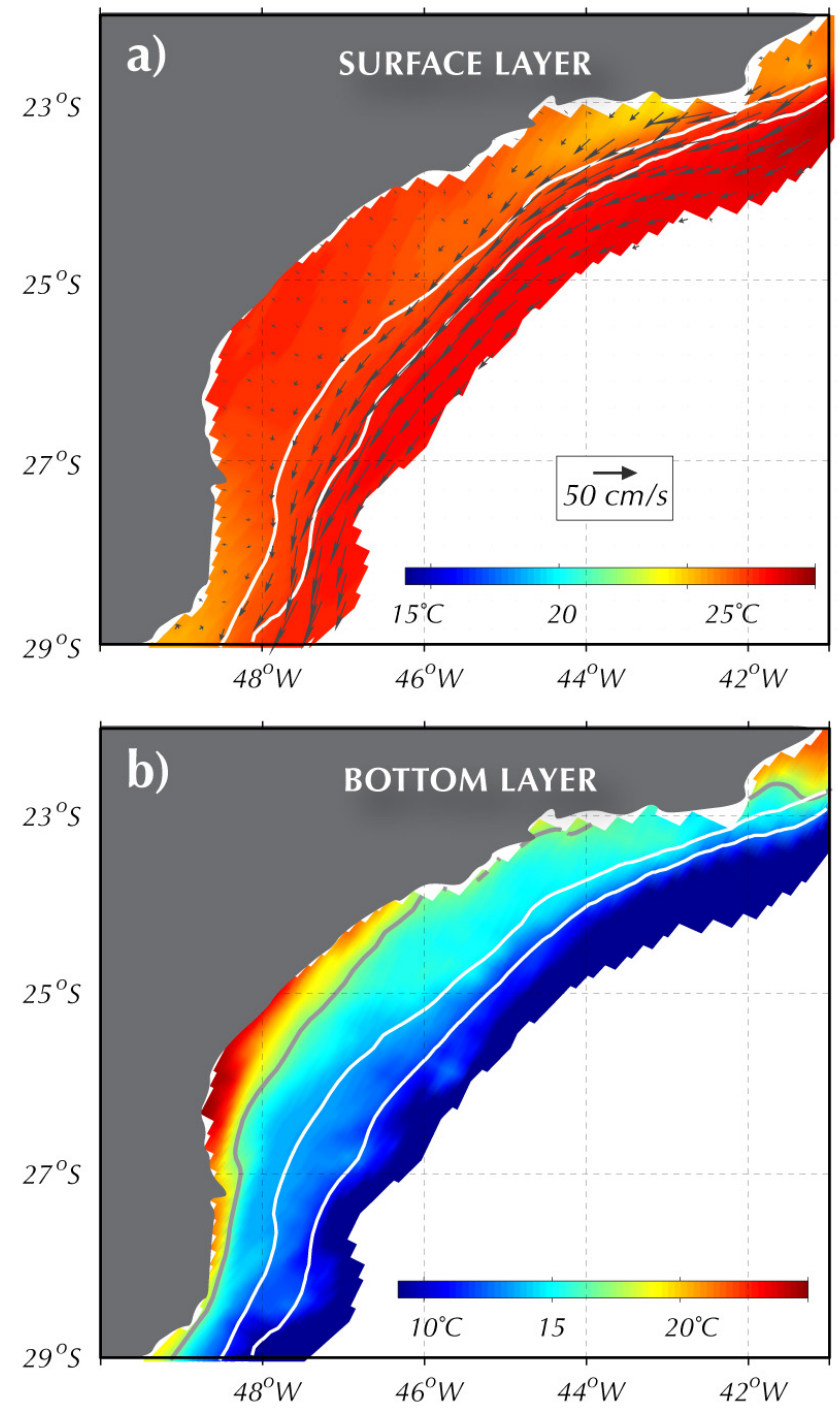

Fig. 4. EXP2: (a) Summer sea surface temperature and surface velocity vectors and (b) Bottom temperature. White contours mark the 100 and 200 isobaths. The black line in panel (b) is the $17^{\circ} \mathrm{C}$ isotherm, indicative of the SACW penetration. Note that each panel uses a different color bar.

in the bottom boundary layer are appreciated in the location of the $17^{\circ} \mathrm{C}$ isotherm, which is representative of SACW, and which moves closer to the coast during the summer months (Fig. 4b). As noted above, upwelling favorable winds (in EXP1) further draw these waters toward the coast and force their outcrop to the surface (Fig. 3b).

To further quantify the influence of the $\mathrm{BC}$ on the shelf circulation we calculated the alongshelf momentum balances in the bottom boundary layer (Fig. 5). There is little difference between the curves representing the Coriolis term $(f . U)$ in the middle and outer shelf but there are important differences in the inner shelf. This indicates that the cross-shelf velocities of the outer and middle shelf are largely driven by the 


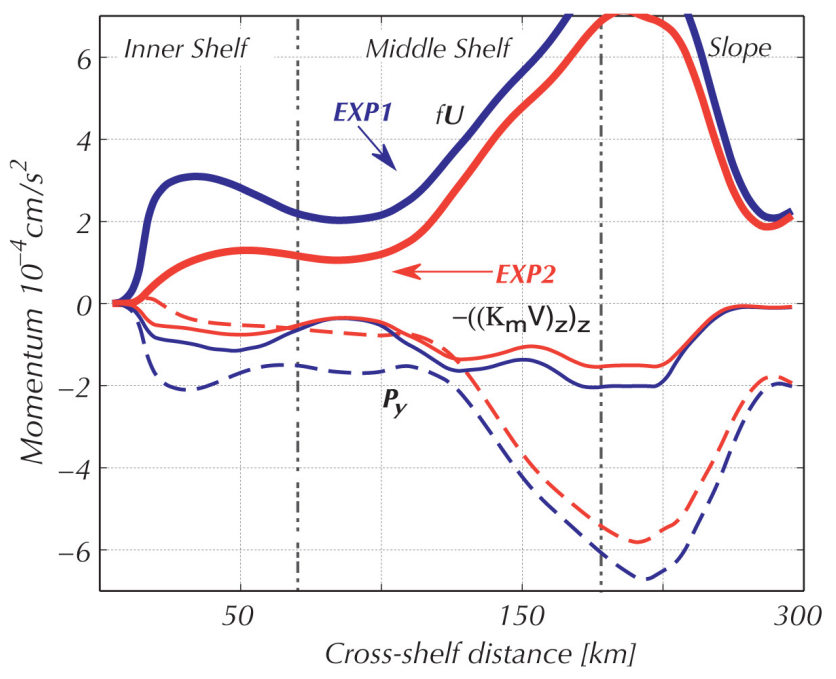

Fig. 5. Alongshelf component of the momentum balance across section $\mathrm{C}$ during summer.

barotropic pressure gradient associated with the Brazil Current, while direct wind forcing significantly influences the cross-shelf velocities in the inner-shelf. Further analysis by Palma and Matano (2009) shows that changes in the coastline orientation modify the spatial patterns of cross-shelf exchanges. In particular the latitudinal change of the shelf width reverses the direction of the alongshelf pressure gradient and augments the onshore flow towards the north.

In summary, our experiments indicate that the water mass structure and circulation of the SBB is controlled by the synergetic interaction between wind-driven upwelling in the inner shelf and onshore intrusions of the BC in the middle and outer shelf. The wind effect peaks during the austral summer and decreases towards the winter while the influence of the BC shows no significant seasonal variation. As shown in previous work the circulation patterns and density structures derived from the numerical simulations correspond well with observations (Campos et al., 1995; Palma and Matano, 2009). The interaction between the poleward flow of the BC and the bottom topography greatly influences the nearshore circulation, particularly in the bottom boundary layer. Changes of the width of the SBB modulate the alongshore pressure gradient and the magnitude of the shelfbreak upwelling and downwelling. Thus, although the summer upwelling winds extend over the entire region the SSTs are warmer in the south because of the cooling effect of the shelfbreak upwelling in the northern region. As noted by Palma and Matano (2009), the narrowing of the shelf in the southern portion of the bight leads to an enhancement of the vertical mixing in some situations (e.g., when there is an increase in the $\mathrm{BC}$ transport or the magnitude of the windstress forcing) and can overcome the unfavourable alongshore pressure gradient and promote upwelling.

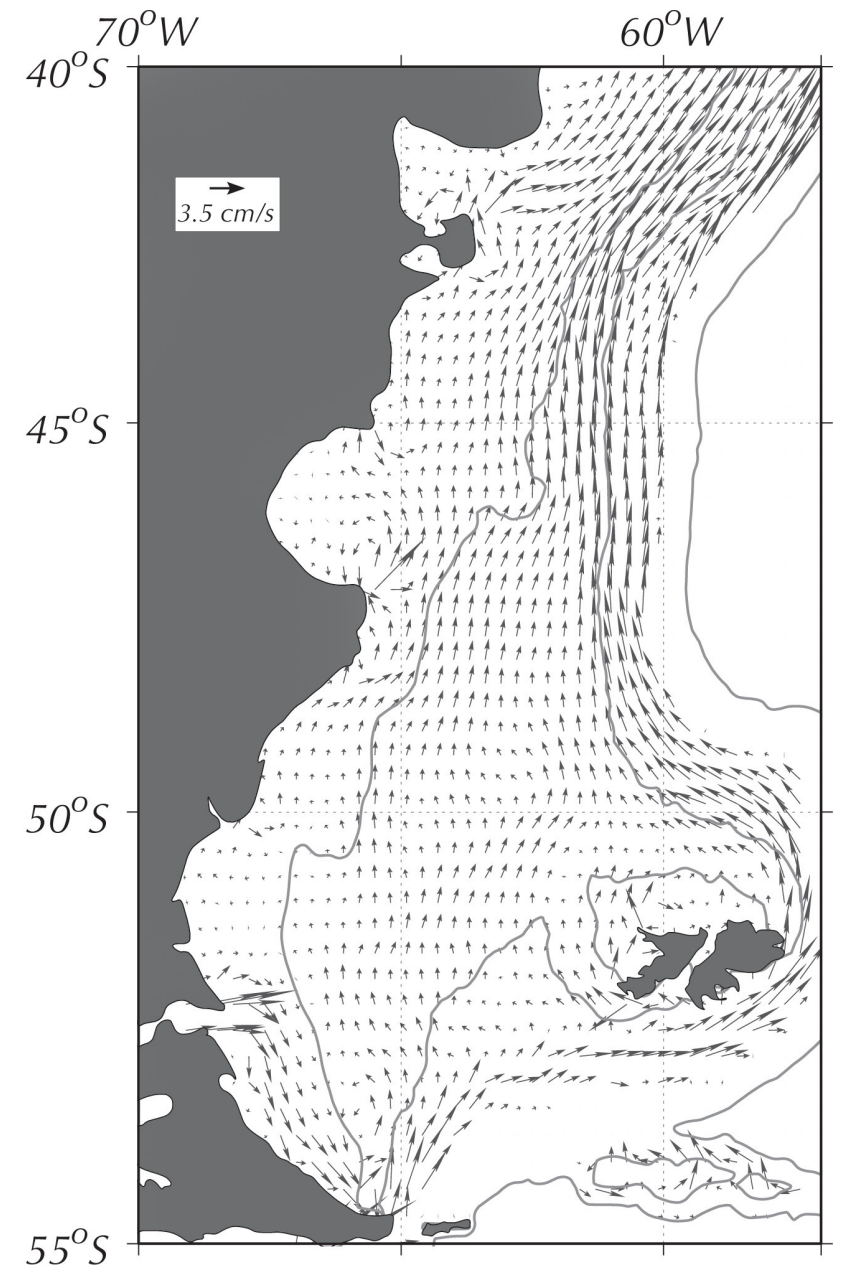

Fig. 6. Depth averaged circulation over the Patagonia shelf (depths smaller than $500 \mathrm{~m}$ ), in EXP1.

\section{The influence of the MC on the Patagonian shelf}

The Patagonian shelf extends from the tip of South America $\left(\sim 55^{\circ} \mathrm{S}\right)$ to the Brazil/Malvinas Confluence $\left(\sim 38^{\circ} \mathrm{S}\right)$ (Fig. 1). This vast coastal region is subject to the combined effects of strong westerly winds, high amplitude tides, large low-salinity discharges, and the neighboring presence of the MC. Its mean circulation is characterized by a broad northeastward flow that intensifies towards the shelfbreak, where it merges with the MC (Figs. 1 and 6). South of $\sim 49^{\circ} \mathrm{S}$ there is a well-defined jet in the inner shelf, known as the Patagonian Current, that is generated through the interaction of tidal currents and the Magellan Straits discharge (Palma et al., 2008) (Fig. 1). The vertical structure of the shelf circulation is roughly equivalent to a two-layer system, with the flow in the upper layer directed towards the northeast and in the bottom layer towards the southwest (Fig. 7a and c). A simple mass balance shows that the northward outflow of surface waters is compensated by inflow at deeper levels. The largest entrainment of deep waters is observed through the 

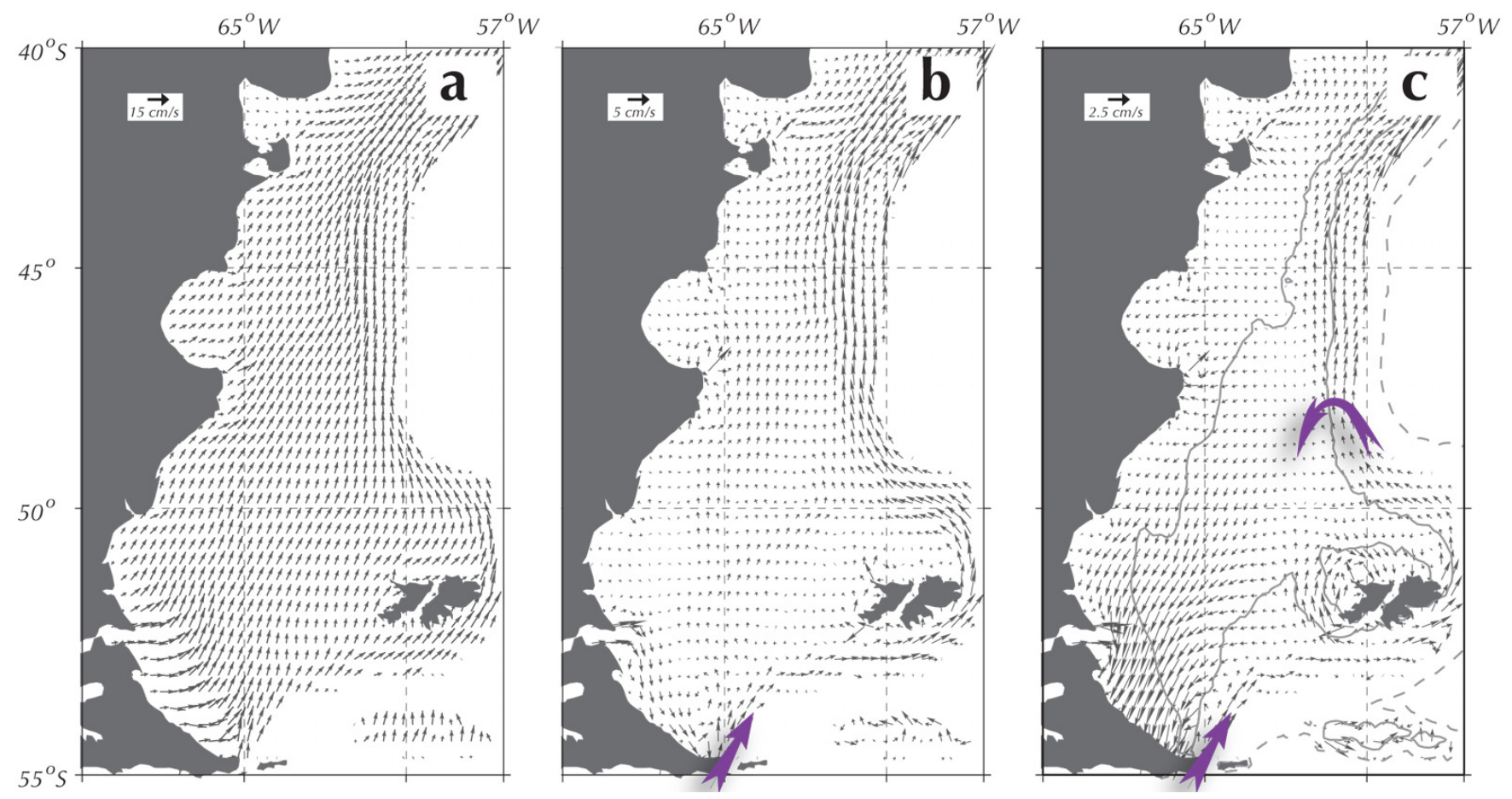

Fig. 7. Time averaged velocities at the upper, intermediate, and bottom levels of EXP1. The purple arrows mark the regions of largest cross-shelf exchanges.

Le Maire Straits (at the tip of Tierra del Fuego) and to the north of the Malvinas Islands (Fig. 7b, c). Similar intrusions have been reported in observations e.g., Sabatini et al. (2004, their Fig. 8) and Romero et al. (2006, their Fig. 8). As these waters move onshore they generate coastal upwelling along the southern portion of Patagonia. This coastal upwelling, however, is relatively weak and it is not easily visualized in the SST fields due to intense tidal mixing (Rivas and Pisoni, 2010).

One of the most distinct characteristics of the Patagonian region is the narrow and persistent chlorophyll maximum that closely follows the $200 \mathrm{~m}$ isobath (Romero et al., 2006) (Fig. 8). The peaks of this maximum are unusually high. Spring blooms, for example, have surface values of 25$30 \mathrm{mg} / \mathrm{m}^{3}$, which are an order of magnitude larger than those observed in typical offshore locations (e.g., Acha et al., 2004; Romero et al., 2006; Garcia et al., 2008; Signorini et al., 2009). The chlorophyll blooms of the MC are symptomatic of the upwelling of nutrient-rich waters to the surface, but the mechanisms driving such upwelling are still poorly understood. External forcing does not appear to be the cause: the winds in the Patagonia region are not upwelling-favorable, tidal mixing is relatively small in the shelfbreak region and, as noted above, the MC does not show the eddy shedding and meandering that drive the upwelling of other western boundary systems (e.g., the Gulf Stream). It has been recently postulated that the shelfbreak upwelling of Patagonia is associated with frictionally driven intrusions of the
MC onto the shelf (Matano and Palma, 2008). These intrusions generate an alongshelf pressure gradient with a secondary cross-shelf divergence cell that leads to shelfbreak upwelling. The magnitude of the upwelling is proportional to the transport of the $\mathrm{MC}$ and to the ratio of the bottom slopes at both sides of the shelfbreak (Matano and Palma, 2008). The upwelling of Patagonia is qualitatively and quantitatively different than that proposed for the shelfbreak of the Middle Atlantic Bight, its northern hemisphere counterpart, because of the fact that the former lacks the equivalent of the Labrador Current while the latter lacks the equivalent of the MC. Modeling studies indicate that the upwelling velocities along Patagonia's shelfbreak are of the same order of magnitude as those in typical wind-driven upwelling systems (Matano and Palma 2008). The difference is that, while most wind-driven events last only a few days or weeks, the upwelling of Patagonia can be continuously sustained throughout the entire year. There are coastal regions with year-round upwelling favorable winds (e.g., the western coast of Africa) but, unlike Patagonia, they are not embedded within the nutrient rich waters of the Southern Ocean and their influence is restricted to the nearshore region. The impact of Patagonia's shelfbreak upwelling on the regional ecosystems appears to extend well beyond the shelfbreak region. Chlorophyll-a images, for example, indicate that the subpolar portion of the South Atlantic is the most productive portion of the entire Southern Ocean while the subtropical open-ocean region is a relative desert $\left(<0.2 \mathrm{mg} / \mathrm{m}^{3}\right.$, Fig. 8). 


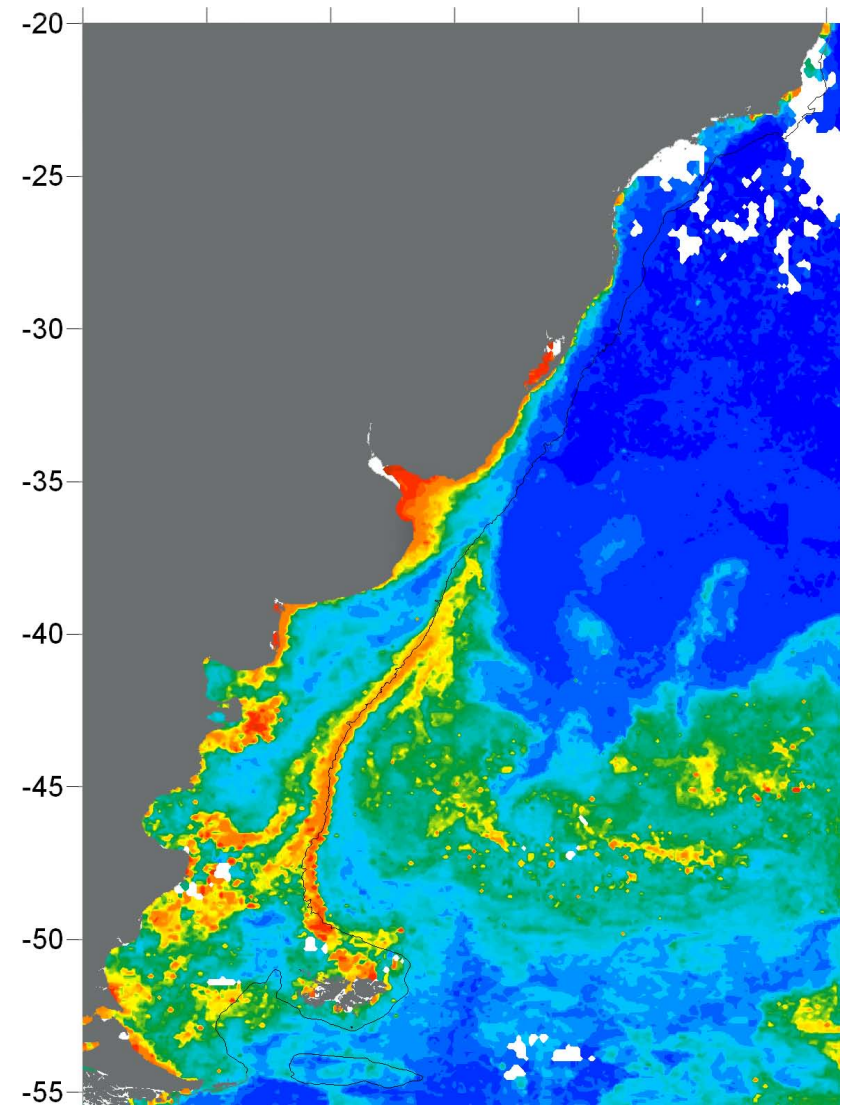

Fig. 8. SeaWiFS derived surface chlorophyll distribution averaged between 17-24 January 2009 in the southwestern Atlantic region.

The influence of the MC on the coastal circulation is more easily appreciated by comparing the results of EXP1 with a barotropic experiment that excludes the MC (Fig. 9). The remarkable differences between these experiments shows that the influence of the MC extends from the outer to the inner shelf. The cross-shelf component of the vertically averaged momentum balance, for example, indicates a 2- to 4-fold increase of the alongshelf transport. This increase reflects the influence of the barotropic pressure gradient associated with the MC and is particularly noticeable in the middle shelf. Note that in EXP3 there is no net alongshelf transport and, therefore, the northward wind-driven transport in the surface Ekman layer is compensated by a similar southward transport in the bottom boundary layer. In EXP1, however, there is a substantial net alongshelf transport whose spatial variations reflect the mass exchanges between the shelf and the deep ocean that are generated by the MC.

The Patagonian shelf exports surface waters to the deep ocean and imports deeper waters through the Le Maire Straits and the shelfbreak region (Fig. 7). Shelfbreak upwelling draws cold and denser waters to the surface whence they move onshore and downward. After reaching the middle and inner shelf these waters are uplifted towards the surface by
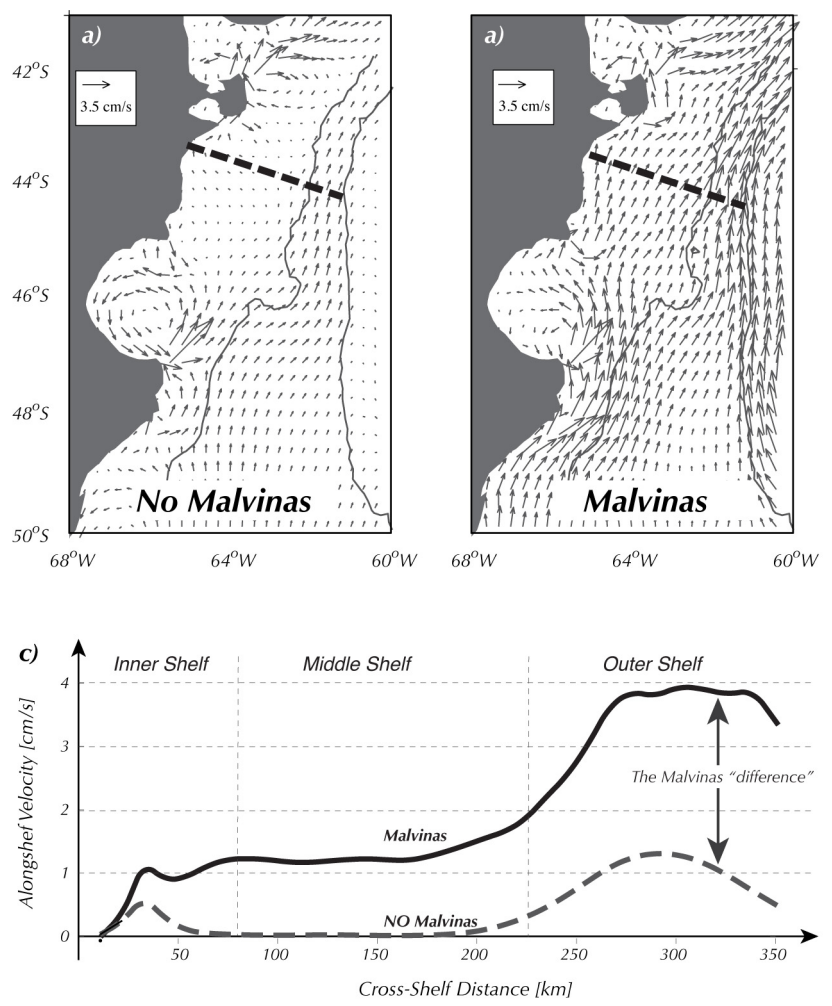

Fig. 9. (a) Depth averaged velocities in EXP2; (b) EXP1; (c) Alongshelf velocities across the section shown in the upper panels. The differences between these two experiments are mainly due to the MC.

strong tidal mixing and are diverted to the north in the surface Ekman layer (Fig. 10). The nutrients carried by these waters add to the nutrient flux produced by re-suspension and cause additional chlorophyll blooms along the inner- and middleshelf of Patagonia (Fig. 8). These cross-shelf exchange patterns are consistent with observations. A cross-shelf hydrographic section across $51^{\circ} \mathrm{S}$, for example, typifies the water mass structure and circulation of this region (Fig. 11a). The density profile shows a typically weak pycnocline and a small wedge of low-density waters very close to the shore. This coastal minimum is associated with the presence of fresher waters from the Magellan Strait. Farther offshore there is a second density front at approximately $300 \mathrm{~km}$ from the coast. This front marks the boundary between the coastal and shelf water masses. The advection of sub Antarctic waters by the $\mathrm{MC}$ is evident over the outer continental shelf where there are sharp gradients of temperature and salinity in the deep layers. The isopycnals show three retrograde fronts, which have been associated with the development of baroclinic cells of circulation (Fig. 11b). Thus, model and observations suggest a cross-shelf circulation pattern dominated by upwelling and onshore intrusions of cold and dense Malvinas water in the outer shelf. After moving away from the shelfbreak these waters sink and are drawn to the inner shelf where they are lifted 


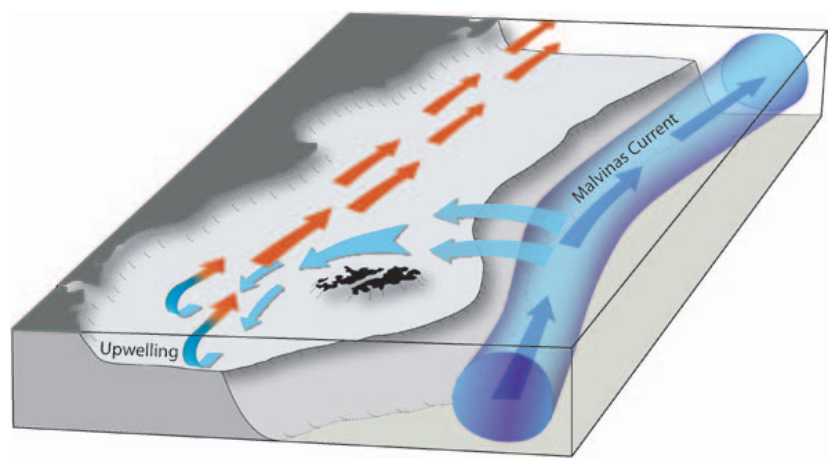

Fig. 10. Schematic representation of the cross-shelf exchanges in the Patagonia shelf region. Sub Antarctic waters upwelled along Patagonia's shelfbreak move onshelf and sink. Near the coast these waters are drawn upward by tidal mixing, and after reaching the surface they are advected to the north by the westerly winds. A portion of these waters is likely to be diverted offshore in the surface Ekman layer while the remainder might reach the Brazil/Malvinas Confluence and the STSF where they are likely to be detrained by the mean circulation.

again by tidal forcing. As these waters reach the mixed layer they are diverted to the north by the westerly winds (Fig. 10). The inshore flux through the Patagonia shelf is compensated by offshore fluxes at the Brazil/Malvinas Confluence and at the STSF.

In a recent study Piola et al. (2010) also showed intrusions of the MC onto the northern Patagonian shelf near $41^{\circ} \mathrm{S}$. These intrusions, which extend throughout the entire water column, generate low temperature and high salinity anomalies that extend through the midshelf region. These onshore intrusions of the MC are also associated with distinct chlorophyll peaks, such as the one observed in spring 2003 (Piola et al., 2010; Signorini et al., 2009). The mechanisms generating these intrusions are still poorly understood although it appears to be due to topographic steering of the MC; the inshore turn of isobaths within the $90-110 \mathrm{~m}$ depth range might drive inshore waters from the western edge of the MC.

\section{The Subtropical Shelf Front (STSF)}

Located near $33^{\circ} \mathrm{S}$, the STSF separates the warm and salty waters of the SBB from the cold and relatively fresh waters of the Patagonian Shelf (Fig. 12a). The STSF extends from the near surface, where it is capped by low salinity waters drawn from the La Plata River and the Patos/Mirim complex, to the bottom (Fig. 12b). Although the front appears as a shelf extension of the Brazil/Malvinas Confluence, the contribution of the western boundary currents to its formation remains unclear. Piola et al. $(2000,2008)$ observed that while the Brazilian sector of the shelf shows inshore intrusions of the Brazil Current (manifested as SACW in their T-S diagrams), the waters in the Argentinean sector are substantially fresher

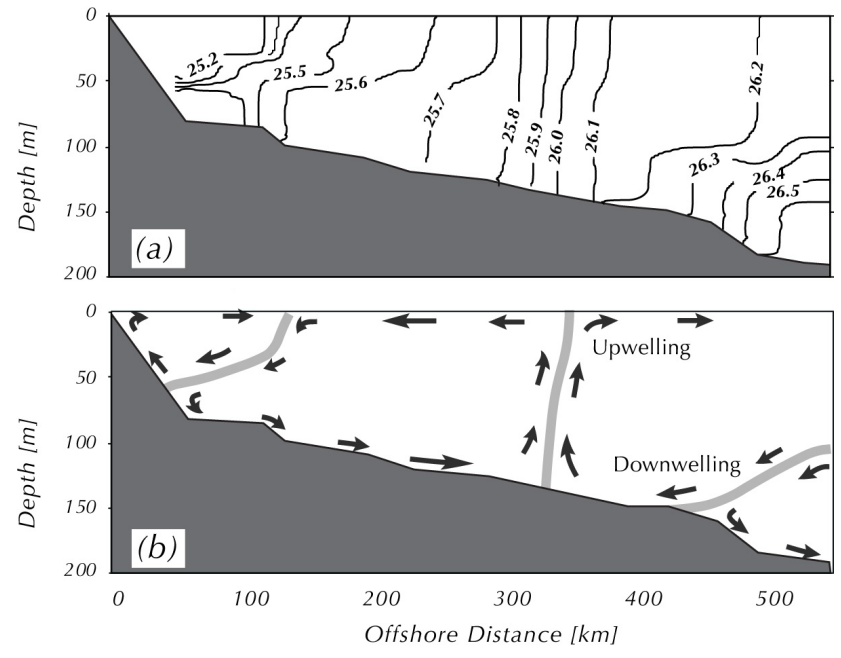

Fig. 11. Density cross-shelf section off Grande Bay $\left(\sim 51^{\circ} \mathrm{S}\right)$ from a hydrographic cruise in March 1994 (top panel). Schematic showing the fronts identified in this section and the inferred circulation patterns. (After Sabatini et al., 2004).

than those carried by the Malvinas Current. Thus, while there is evidence that the $\mathrm{BC}$ moves over the shelf, and therefore might influence the frontal structure, there is no evidence of similar behavior by the Malvinas Current. The cross-shelf sections analyzed by Piola et al. (2008) also indicate that there is neither northward penetration of sub-Antarctic shelf waters to the north of the front nor southward penetration of the subtropical shelf waters to the south. Both water masses, therefore, should be advected offshore at this location.

As noted above, it remains unknown what are the dynamical mechanisms that lead to the formation and determine the location of the STSF. Like the Cape Hatteras Front, its northern hemisphere counterpart (Stefansson et al., 1971; Pietrafesa et al., 1994; Savidge, 2002), the STSF appears to be an onshore extension of the barotropic pressure gradients associated with the neighboring western boundary currents. This hypothesis is reinforced by observations showing that the front is essentially barotropic, i.e., that it has a density compensated thermohaline structure. Thus, there is a distinct front in temperature and salinity but not in density (Piola et al., 2000). Although observations show direct intrusions of waters of the $\mathrm{BC}$ onto the shelf, but not from the MC, numerical experiments indicate that the MC still plays an important role in the front location through its barotropic pressure gradient (Palma et al., 2008). The STSF appears to be a preferential region for the detrainment of the cross-shelf inflows from the BC and MC (Fig. 13). Thus, waters entrained throughout the shelfbreaks of the SBB and Patagonia are ejected offshore in this region. The bio-geochemical properties of these water masses are enhanced by the freshwater discharges from the La Plata River and the Patos/Mirim Lagoon, making the STSF a critical component of the cross-shelf exchanges in the Southwestern Atlantic. 

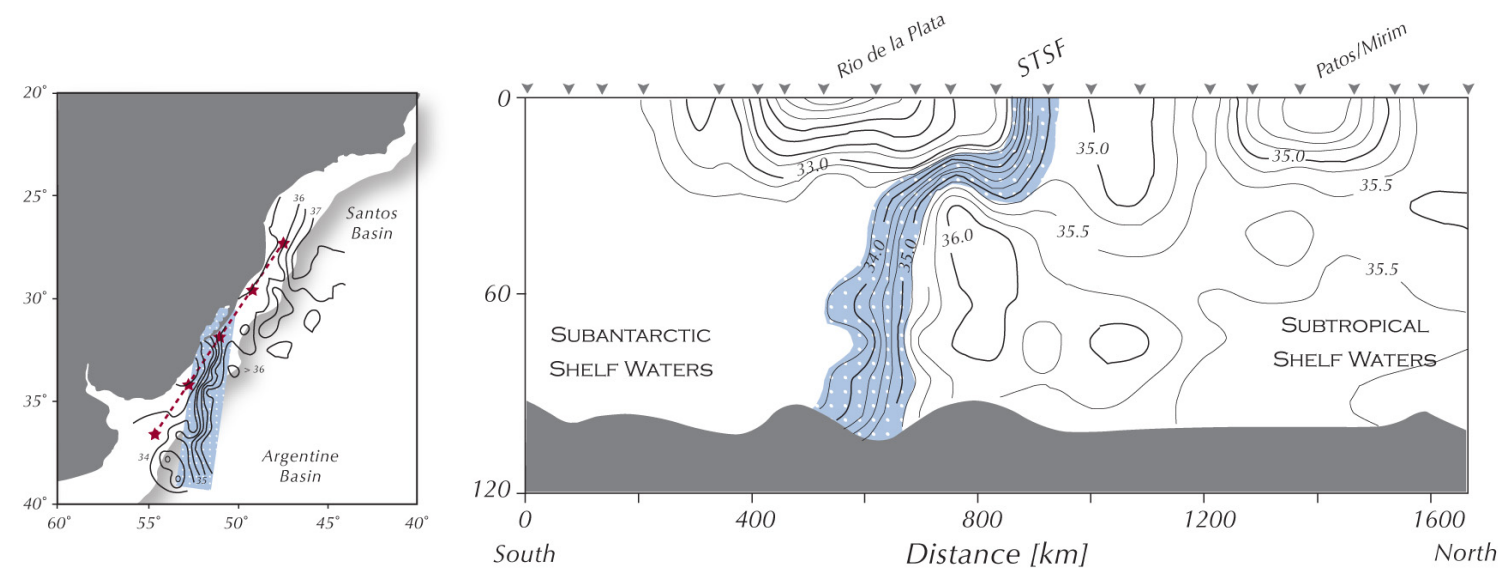

Fig. 12. Sea surface salinity (left panel) and alongshelf salinity transect (right panel). The stippled area marks the location of the STSF. Adapted from Piola et al. (2000).

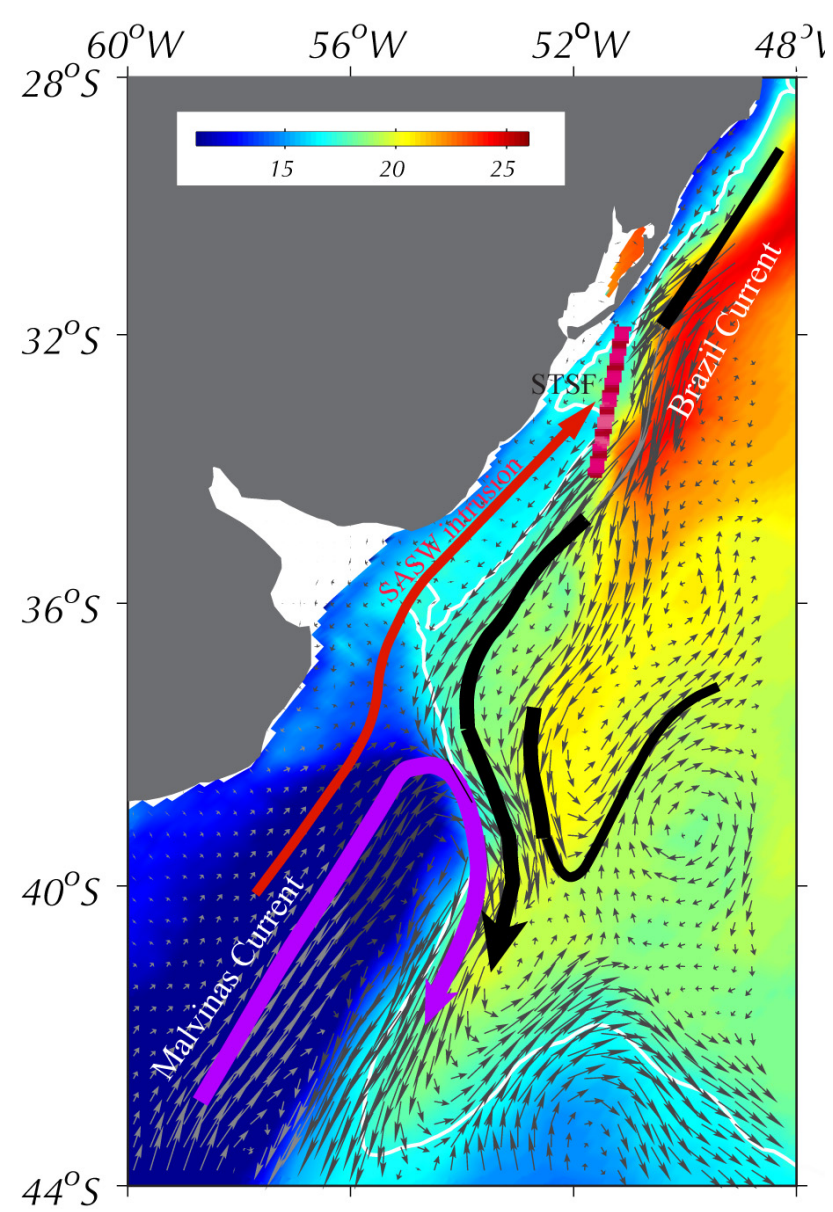

Fig. 13. Snapshot of SST and velocitities in EXP1. This figure shows a classic configuration of the circulation in this region, which is characterized by the detrainment of shelf waters onto the deep ocean.

\section{Summary and discussion}

In this article we reviewed the influence of the $\mathrm{BC}$ and $\mathrm{MC}$ on the circulation of the southwestern Atlantic shelf. The influence of the $\mathrm{BC}$ is most visible through sporadic onshore intrusions of eddies and meanders, but it has been argued that this is not the only - nor its most important - contribution to the shelf dynamics. In fact, numerical simulations show that the thermohaline structure of the SBB can be entirely ascribed to steady state, bottom boundary layer processes. The determination of the cross-shelf exchanges over Patagonia is much simplified by the weak density stratification of the region, which basically locks the path of the MC to the bottom topography inhibiting the development of mean flow instabilities. Drifter trajectories in this region, for example, do not show the convoluted loops that characterize the path of unstable currents, but extend from the Drake Passage to the Brazil/Malvinas Confluence in remarkably smooth tracks (Fig. 14). This characteristic of the MC allows the use of a well-developed body of theoretical models to identify the region most favorable for cross-shelf exchanges. For example, the arrested topographic wave theory of Csanady (1978) predicts that the onshore penetrations of the MC onto the shelf should be inversely proportional to the steepness of the continental slope. Regions of steep slope, therefore, should allow a smaller penetration than regions with gentler slopes. Based on these arguments, Hill (1995) argued that if the transition between two regions occurs in a distance smaller than that required by the geostrophic adjustment $\left(L \sim f h_{x} b^{2} / r\right.$, where $h_{x}$ is the bottom slope, $b$ is the width of the western boundary current, and $r$ is the bottom friction coefficient), ageostrophic effects should generate substantial cross-shelf flows to account for the disparity in the bottom slopes. There is a welldefined transition in the steepness of the continental slope between $\sim 50^{\circ} \mathrm{S}$ and $48^{\circ} \mathrm{S}$ (Fig. 15). This transition occurs in a distance of less than $300 \mathrm{~km}$, which is much smaller than the 


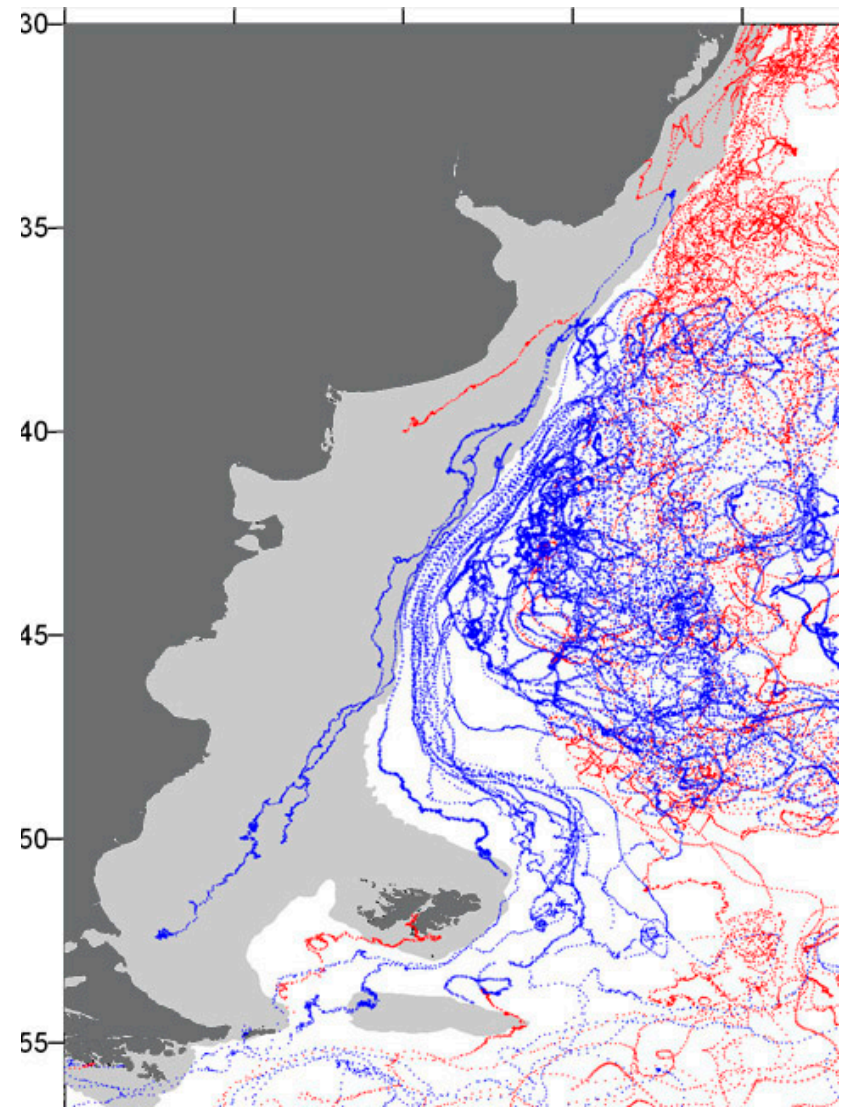

Fig. 14. Trajectories of satellite tracked "surface" drifters from WOCE-Surface Velocity Program type. The drifters are drogued to $15 \mathrm{~m}$ depth and designed to follow the water to within $\pm 013 \mathrm{~m} \mathrm{~s}^{-1}$ in $10 \mathrm{~m} \mathrm{~s}^{-1}$ winds (Niiler et al., 1995). The original position data have been quality controlled and optimally interpolated to uniform six-hour interval trajectories (Hansen and Poulain, 1996). Note the quasi-linear trajectoriesof the drifters in the MC.

scale required by geostrophic adjustment, i.e., $L \sim 2000 \mathrm{~km}$ (considering a $f=2 \times 10^{-4} \mathrm{~s}^{-1}, r=10^{-3} \mathrm{~ms}^{-1}, b=100 \mathrm{~km}$, and $\left.h_{x}=1 \times 10-3\right)$. Hill's hypothesis is in good agreement with the results of the numerical simulation (e.g., Fig. 7c). The arrested topographic wave theory, however, is strictly valid for a barotropic fluid and although the MC is very weakly stratified it still needs to be determined whether the downstream topographic scale is indeed much smaller than the geostrophic adjustment scale for the MC. It seems likely that the strong entrainment observed in the region to the north of the Malvinas Islands is partly explained by Hill's hypothesis and partly by non-linear ageostrophic effects associated with the narrowing of the $\mathrm{MC}$ and the curvature of its path, i.e., confronted with a sudden turn of the bottom topography inertia can force a portion of the MC to "spill over" the shelf.

The inflow through the Le Maire Strait is not restricted to the bottom boundary layer but extends throughout the entire water column, thus suggesting a different entrainment

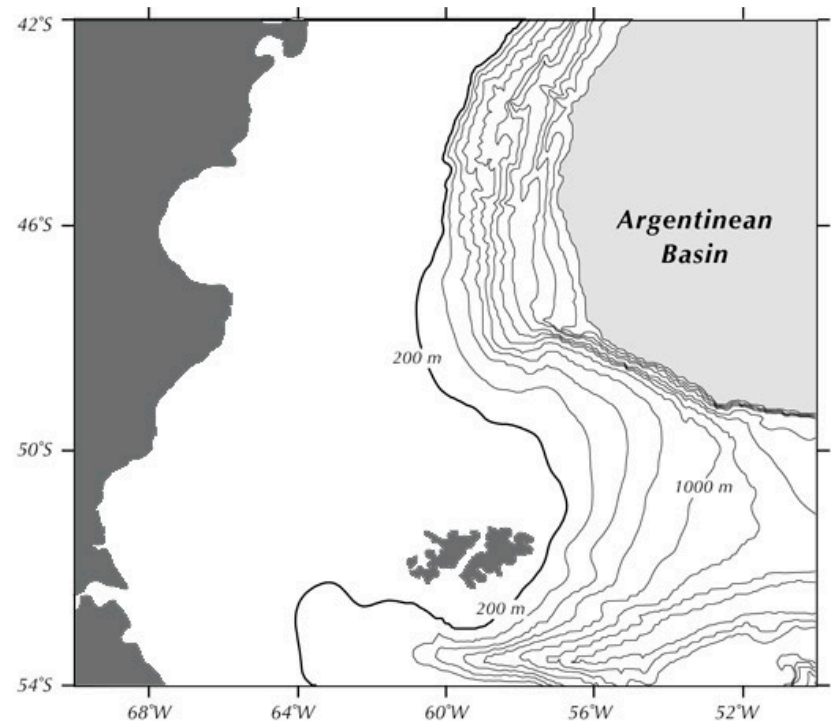

Fig. 15. Bottom topography of the Patagonian shelf. Note the rapid convergence of the isobaths north of $\sim 50^{\circ} \mathrm{S}$.

mechanism (Fig. 7). We surmise that cross-shelf fluxes in this region are driven partly by inertial fluxes across bending isobaths, and partly by the interaction of the $M_{2}$ tide with the bottom topography. Similar processes have been identified in George's Bank where it was observed that enhanced vertical mixing and horizontal gradients lead to secondary circulation cells that account for most of cross-shelf fluxes (Franks and Chen, 1996). In these regards it should be noted that southern Patagonia has one of the largest $M_{2}$ tide amplitude range of the world ocean. Tides are unlikely to play an equally important role in the northern region because the M2 tide enters Patagonia through its southern boundary and travels as a Kelvin wave with its maximum amplitude largely confined to the inner shelf (Palma et al., 2004). Wind stress forcing is another important promoter of cross-shelf exchanges. Pringle (2002) postulated that alongshelf variations of the shelf width should generate cross-shelf fluxes that compensate for changes of the wind-driven Ekman transports. According to this theory the observed narrowing of the Patagonia shelf in the region between $\sim 50^{\circ} \mathrm{S}$ and $48^{\circ} \mathrm{S}$, should favor an outflow of shelf waters onto the deep ocean. However, as noted in our previous discussion, this region is also characterized by an abrupt change of the continental slope that should intensify the intrusion of the MC onto the shelf. The cross-shelf fluxes associated with the MC and the shelf circulation, therefore, oppose each other and, in principle, should lead to a further strengthening of the alongshelf circulation north of $\sim 48^{\circ} \mathrm{S}$. Interestingly this strengthening can be inferred from observations and it is a ubiquitous feature of our previous numerical simulations (e.g., Fig. 7). 


\section{Perspectives}

Although our understanding of the exchanges between the deep ocean and the southwestern Atlantic shelf is very limited it is obvious that their nature and magnitude vary dramatically from north to south. So do the questions concerning each of its distinct regions. A central question concerning the exchanges in the South Brazil Bight is whether they are controlled by eddy fluxes or by steady intrusions from the bottom boundary layer. This is a difficult question because transient and mean flows are naturally concatenated, but it is important because it concerns properties of the exchanges such as nutrient content, residence time, etc. It is difficult to address this question using observations. Satellite measurements, for example, display eddy-like features along the onshore edge of the Brazil Current, but these data are only representative of the ocean surface. Hydrographic and current meter observations are scarce, and, due to the extent of the region, acquisition of new data is logistically difficult and expensive. New numerical simulations, however, can help the design of observational programs. For example, realistic models can be used to assess the location of the main cross-shelf exchanges, while process-oriented simulations can help to elucidate the dynamical processes responsible for those exchanges. Considering that one of the crucial problems of comparing actual simulations is their dissimilarities, i.e., spatial and temporal domain, mixing parameterization, spatial resolution, etc., it seems particularly important to encourage model developments that allow the assessment of the robustness of the results. One of the portions of the South Brazil Bight that seems more interesting for focused numerical and observational studies is the Cape Frio region, where the curvature of the coastline and the narrowness of the shelf synergize the interaction between local and remotely forced phenomena.

Patagonia is one of the most interesting portions of the southwestern Atlantic shelf, not only because of its high primary production, but also because it is the main conduit for terrigenous fluxes into the Southern Ocean. Thus, determining the magnitude and nature of its cross-shelf fluxes is relevant to our understanding of the entire Southern Ocean ecological system. Fortunately, these exchanges appear to be more amenable to modeling and observational studies than other shelf regions, partly due to the weak density stratification in the outer shelf and partly to the remarkable stability of the Malvinas Current. A central question is whether these cross-shelf fluxes are modulated by the bottom topography and variations in the transport of the MC. These questions have been addressed in highly idealized models e.g., Hill (1995), Matano and Palma (2008) but it remains to be seen whether the same results are apparent in more realistic simulations.

Present simulations suggest that most of the waters entrained in the SBB and the Patagonia shelf are detrained near the Brazil/Malvinas Confluence and the Subtropical Shelf
Front. The circulation in this middle region, therefore, appears to be key component of the processes connecting the southwestern Atlantic shelf to the deep ocean.

Acknowledgements. We would like to acknowledge the comments of C. Provost and an anonymous reviewer. R. P. Matano acknowledges the financial support of the National Science Foundation throughgrants OCE-0726994 and OCE-0928348, and NASA through grant NNX08AR40G. E. D Palma acknowledges the financial support from CONICET (PIP09-112-200801), Agencia Nacional de Promoción Científica y Tecnológica (PICT08-1874), and funding from the Universidad Nacional del Sur (24F044). A. R. Piola acknowledges a grant from the Inter-American Institute for Global Change Research (IAI) CRN 2076 which is supported by the US National Science Foundation (GEO-0452325), and support from the Universidad de Buenos Aires (UBACyT08-10 X176), CONICET (PIP09-112-200801), and Agencia Nacional de Promoción Científica y Tecnológica (PICT08-1874).

Edited by: J. A. Johnson

\section{References}

Acha, E. M., Mianzan, H. W., Guerrero, R. A., Favero, M., and Bava, J.: Marine fronts at the continental shelves of austral South America, physical and ecological processes, J. Mar. Syst., 44, 83-105, 2004.

Bianchi, A. A., Bianucci, L., Piola, A. R., Pino, D. R., Schloss, I., Poisson, A., and Balestrini, C. F.: Vertical stratification and airsea CO2 fluxes in the Patagonian shelf, J. Geophys. Res., 110, C07003, doi:10.1029/2004JC002488, 2005.

Bianchi, A. A., Ruiz-Pino, D., Isbert Perlender, H., Osiroff, A., Segura, V., Lutz, V., Luz Clara, M., Balestrini, C. F., and Piola, A. R.: Annual balance and seasonal variability of sea-air $\mathrm{CO} 2$ fluxes in the Patagonia Sea: Their relationship with fronts and chlorophyll distribution, J. Geophys. Res., 114, C03018, doi:10.1029/2008JC004854, 2009.

Boyer, T. P., Antonov, J. I., Baranova, O. K., Garcia, H. E., Johnson, D. R., Locarnini, R. A., Mishonov, A. V., Seidov, D., Smolyar, I. V., and Zweng, M. M.: World Ocean Database, Chapter 1: Introduction, NOAA Atlas NESDIS 66, edited by: Levitus, S., U.S. Gov. Printing Office, Wash., D.C., 216 pp., DVD, 2009.

Brandhorst, W. and Castello, J. P.: Evaluación de los recursos de anchoíta (Engraulis anchoita) frentea la Argentina y Uruguay. Las condiciones oceanográficas, sinopsis del conocimiento actual sobre la anchoíta y el plan para su evaluación. Contr. Inst. Biol. Mar., Argentina, 166, 1-63, 1971.

Campos, E. J., Goncalves, J., and Ikeda, Y.: Water mass characteristics and geostrophic circulation in the South Brazil Bight: Summer of 1991, J. Geophys. Res., 100, 18537-18550, 1995.

Campos, E. J., Velhote, D., and da Silveira, I. C.: Shelf break upwelling driven by Brazil Current cyclonic meanders, Geophys. Res. Lett. 27, 6, 751-754, 2000.

Castelao R. M, Campos, E. J. D., and Miller, J. L.: A modelling Study of Coastal Upwelling Driven by Wind and meanders of the Brazil Current, J. Coast. Res., 20, 3, 662-671, 2004.

Csanady, G. T.: The arrested topographic wave, J. Phys. Oceanogr. 8, 47-62, 1978. 
Csirke, J.: The Patagonian fishery resources and the offshore fisheries in the South-West Atlantic, FAO Fisheries Technical Paper 286, 75 pp, 1997.

FAO, Fisheries and Aquaculture Statistics, 2007 Yearbook, Rome, 72 pp., 2009.

Franks, P. J. S. and Chen, C.: Plankton production in tidal fronts: A model of Georges Bank in summer, J. Mar. Res., 54, 631-651, 1996.

Garcia, V. M. T., Garcia, C. A. E., Mata, M. M., Pollery, R. C., Piola, A. R., Signorini, S. R., McClain, C. R., and IglesiasRodriguez, M. D.: Environmental factors controlling the phytoplankton blooms at the Patagonia shelf-break in spring, DeepSea Res. Pt. I, 55(9), 1150-1166, doi:10.1016/j.dsr.2008.04.011, 2008.

Gordon, A. L.: Brazil - Malvinas Confluence - 1984, Deep Sea Res. Pt. 1, 36, 359-384, 1989.

Haimovici, M., Rossi-Wongtchowski C., Cergole, M. C., Bernardes, R. A., and Avila da Silva, A. O.: Capitulo 6: Recursos pesqueiros da regiao sudeste-sul, in: Ministerio do Meio Ambiente, Progrma REVIZEE: Avaliacao do potencial sustentavel de recursos vivos na zona economica exclusiva: Relatorio executivo/MMA, Secretaria de Cualidade Ambiental, Brasilia, Brazil, 207-242, 2006

Hansen, V. H. and Poulain, P.-M.: Quality control and interpolations of WOCE/TOGA 35 drifter data, J. Atmos. Ocean. Technol., 13, 900-909, 1996

Hill, A. E.: Leakage of barotropic slope current onto the continental shelf, J. Phys. Oceanogr., 25, 1617-1621, 1995.

INIDEP, Gabinete de Oceanografía Física, Instituto Nacional de Investigación y Desarrollo Pesquero, Subsecretaria de Pesca y Acuicultura de la Nación, Mar del Plata, Argentina, http://www. inidep.edu.ar/oceanografia/, 2010.

Lutz, V. A. and Carreto, J. I.: A new spectrofluorometric method for the determination of chlorophyll-a and degradation products and its application in two frontal areas of the Argentine Sea. Cont. Shelf Res. 11(5), 433-451, 1991.

Loder, J. B., Boicourt, W. C., and Simpson, J. H.: Western ocean boundary shelves coastal segment (W), In The Sea, Vol. 11, edited by: Robinson, A. R. and Brink, K. H., 3-27, John Wiley, New York, 1998.

Matano, R. P., Schlax, M. G., and Chelton, D. B.: Seasonal variability in the southwestern Atlantic, J. Geophys. Res., 98, 1802718035, 1993.

Matano, R. P. and Palma, E. D.: On the Upwelling of Downwelling Currents, J. Phys. Oceanogr., 38, 2482-2500, doi:10.1175/2008JPO3783.1, 2008.

Niiler, P. P., Sybrandy, A. L., Bi, K., Poulain, P. M., and Bitterman, D.: Measurements of the water following capability of holey-sock and TRISTAR drifters, Deep-Sea Res., 42, 19511964, 1995.

O'Reilly, J. E., Maritorena, S., O’Brien, M. C., Siegel, D. A., Toole, D., Menzies, D., Smith, R. C., Mueller, J. L., Mitchell, B. G., Kahru, M., Chavez, F. P., Strutton, P., Cota, G. F., Hooker, S. B., McClain, C. R., Carder, K. L., Muller-Karger, F., Harding, L., Magnuson, A., Phinney, D., Moore, G. F., Aiken, J., Arrigo, K. R., Letelier, R., and Culver, M.: SeaWiFS postlaunch calibration and validation analyses, Part 3. NASA Tech. Memo. 2000206892, vol. 11, edited by: Hooker, S. B. and Firestone, E. R., NASA Goddard Space Flight Center, 49 pp., 2000.
Palma, E. D., Matano, R. P., and Piola A. R.: A numerical study of the Southwester Atlantic Shelf circulation: Barotropic response to tidal and wind forcing, J. Geophys. Res., 109, C08014, doi:10.1029/2004JC002315, 2004.

Palma, E. D., Matano, R. P., and Piola, A. R.: A numerical study of the Southwestern Atlantic Shelf circulation: Stratified ocean response to local and offshore forcing, J. Geophys. Res., (C0) 8014, doi:10.1029/2004JC002315, 2008.

Palma, E. D. and Matano, R. P.: Disentangling the upwelling mechanisms of the South Brazil Bight, Cont. Shelf Res., 29, 15251534, doi:10.1016/j.csr.2009.04.002, 2009.

Peterson, R. G.: The boundary current in the western Argentine Basin. Deep Sea Res., 39, 623-644, 1992.

Pietrafesa, L. J., Morrison, J. M., McCann, M. P., Churchill, J., Bohm, E., and Houghton, R. W.: Water mass linkages between the Middle and South Atlantic Bights, Deep Sea Res., Pt. II, 41, 365-389, 1994.

Piola, A. R., Campos, E. J. D., Moller, O. O., Charo, M. and Martinez, C.: Subtropical shelf front off eastern South America, J. Geophys. Res., 105, C3, 6566-6578, 2000.

Piola, A. R. and Matano, R. P.: The South Atlantic Western Boundary Currents Brazil/Falkland (Malvinas) Currents. Encyclopedia of Ocean Sciences. edited by: Steele, J. M., Thorpe, S. A., and Turekian, K. K., Academic Press, 1, 340-349, 2001.

Piola, A. R., Möller Jr, O. O., Guerrero, R. A., and Campos, E. J. D.: Variability of the Subtropical Shelf front off eastern South America: winter 2003 and summer 2004, Cont. Shelf Res., 28, 1639-1648, doi:10.1016/j.csr.2008.03.013, 2008.

Piola, A. R., Martínez Avellaneda, N., Guerrero, R. A., Jardón, F. P., Palma, E. D., Romero, S. I.: Malvinas-slope water intrusions on the northern Patagonia continental shelf, Ocean Sci., 6, 345359,2010

http://www.ocean-sci.net/6/345/2010/.

Pringle, J. M.: Enhancement of wind-driven upwelling and downwelling by alongshore bathymetric variability, J. Phys. Oceanogr., 32, 3101-3112, 2002.

Rivas, A. L. and Pisoni, J. P.: Identification, characteristics and seasonal evolution of surface thermal fronts in the $\mathrm{Ar}$ gentinean Continental Shelf, J. Mar. Syst., 79, 134-143, doi:10.1016/j.jmarsys.2009.07.008, 2010.

Romero, S. L., Piola, A. R., Charo, M., and García, C. E.: Chlorophyll-a variability off Patagonia based on SeaWiFS data, J. Geophys. Res., 111, C05021, doi:10.1029/2005JC003244, 2006.

Sabatini, M., Reta, R., and Matano, R.: Circulation and zooplankton biomass distribution over the southern Patagonian shelf during late summer, Cont. Shelf Res., 24, 1359-1373, 2004.

Saraceno, M., Provost, C., Piola, A. R., Bava, J., and Gagliardini, A.: Brazil Malvinas Frontal System as seen from 9 years of advanced very high resolution radiometer data, J. Geophys. Res., 109, C05027, doi:10.1029/2003JC002127, 2004.

Savidge, D. K.: Wintertime shoreward near-surface currents south of Cape Hatteras, J. Geophys. Res., 107(C11), 3205, doi:10.1029/2001JC001193, 2002.

Signorini, S. R., Garcia, V. M. T., Piola, A. R., Evangelista, H., McClain, C. R., Garcia, C. A. E., and Mata, M. M.: Further studies on the physical and biogeochemical causes for large interannual changes in the Patagonian shelf spring-summer phytoplankton bloom biomass. NASA Technical Memorandum, NASA/TM- 
2009-214176, Greenbelt, MD, 43 pp, 2009.

Spadone, A. and Provost, C.: Variations in the Malvinas Current volume transport since 1992, J. Geophys. Res., 114, C02002, doi:10.1029/2008JC004882, 2009.
Stefansson, L. P. Atkinson, and D. F. Bumpus: Hydrographic properties and circulation of the North Carolina shelf and slope waters, Deep Shelf Res., 18, 383-420, 1971. 